\title{
Tolerance in Islam
}

\begin{tabular}{|c|c|}
\hline \multicolumn{2}{|l|}{$\begin{array}{l}\text { Author: } \\
\text { Shadi Nafisi }{ }^{1,2}\end{array}$} \\
\hline \multicolumn{2}{|c|}{$\begin{array}{l}\text { Affiliations: } \\
{ }^{1} \text { Department of Hadith and } \\
\text { Quranic Sciences, University } \\
\text { of Tehran, Iran }\end{array}$} \\
\hline \multicolumn{2}{|c|}{$\begin{array}{l}{ }^{2} \text { Department of Science of } \\
\text { Religion and Missiology, } \\
\text { Faculty of Theology and } \\
\text { Religion, University of } \\
\text { Pretoria, South Africa }\end{array}$} \\
\hline \multicolumn{2}{|c|}{$\begin{array}{l}\text { Research Project Details: } \\
\text { Project Leader: M. Sukdaven } \\
\text { Project Number: } 04616546\end{array}$} \\
\hline \multicolumn{2}{|c|}{$\begin{array}{l}\text { Project Description: } \\
\text { Prof. Nafisi is participating } \\
\text { in the research project, } \\
\text { 'Religion in Dialogue', } \\
\text { directed by Dr Maniraj } \\
\text { Sukdaven, Department of } \\
\text { Science of Religion and } \\
\text { Missiology, Faculty of } \\
\text { Theology and Religion, } \\
\text { University of Pretoria. }\end{array}$} \\
\hline \multicolumn{2}{|c|}{$\begin{array}{l}\text { Corresponding author: } \\
\text { Shadi Nafisi, } \\
\text { shadinafisi@ut.ac.ir }\end{array}$} \\
\hline \multicolumn{2}{|c|}{$\begin{array}{l}\text { Received: } 08 \text { June } 2018 \\
\text { Accepted: } 10 \text { Aug. } 2018 \\
\text { Published: } 22 \text { Nov. } 2018\end{array}$} \\
\hline \multicolumn{2}{|c|}{$\begin{array}{l}\text { How to cite this article: } \\
\text { Nafisi, S., 2018, 'Tolerance } \\
\text { in Islam', HTS Teologiese } \\
\text { Studies/Theological Studies } \\
\text { 74(3), a5145. https://doi.org/ } \\
\text { 10.4102/hts.v74i3.5145 }\end{array}$} \\
\hline \multicolumn{2}{|c|}{$\begin{array}{l}\text { Copyright: } \\
\text { (c) 2018. The Authors. } \\
\text { Licensee: AOSIS. This wor } \\
\text { is licensed under the } \\
\text { Creative Commons } \\
\text { Attribution License. }\end{array}$} \\
\hline \multicolumn{2}{|l|}{ Read online: } \\
\hline 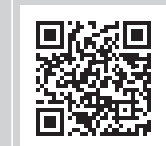 & $\begin{array}{l}\text { Scan this QR } \\
\text { code with your } \\
\text { smart phone or } \\
\text { mobile device } \\
\text { to read online. }\end{array}$ \\
\hline
\end{tabular}

A difference in thought, behaviour and tastes is one of the realities of human life which is rooted in the nature of man's creation; a fact, the acceptance of which requires the development of human society and the increase of its capacity in interaction with different views. This can be interpreted as 'tolerance'. In order to show its importance, human history can be mentioned as good evidence for the widespread atrocities caused by the lack of tolerance. The study of the verses of the Holy Qur'an clarifies the viewpoint of Islam towards this subject matter. What is understood from the Islamic teachings is that Islam does not believe in absolute tolerance in every circumstance. As Islam emphasises tolerance in some conditions, in others it accepts war as a necessity. Meanwhile, Islam maintains the necessity of freedom of belief, that is, freedom of expression and dialogue, as necessary. However, it condemns compromising in belief as well as insufficiency and lack of observance concerning the religious regulations by the believers. Tolerance in Islam is not based on indifference towards religions and beliefs; the necessity of choosing between truth and falsehood and also considering prophets as merely the introducers of truth to the people are the two essential fundamentals of tolerance in belief considering the Islamic view. Besides tolerance in belief, it is necessary to refer to the ethical and behavioural tolerance which provides a cultural ground to materialisation of tolerance in belief; a virtue highly praised and encouraged in Islam.

\section{Statement of the problem}

Despite all the progress which humankind has had in recent centuries in overcoming diseases and managing natural disasters, it has been unable to manage the human anger and violation manifested by wars and conflicts. These conflicts apparently take place in the name of social, political and religious rights, as some of these conflicts have occurred in the name of religion. Amongst religions, Islam is one which is also accused of being harsh towards non-Muslims, particularly with the emergence of violent and militant groups such as al-Qaeda, The Islamic state of Iraq and al-Sham (ISIS) and Boko Haram. These groups show no mercy for either non-Muslims or Muslims of other sects and fractions. The question of this research is whether violence arises from the nature of Islam itself which tries to enforce what it considers right to all the people in the society or whether it is tolerant towards the 'Others'.

The issue of tolerance in Islam has become the focus of attention after September 11 of 2001 in western publications (see Barkey 2005:5; Ghani \& Awang 2017:72; Tyler 2008:3). The issue has been studied from different perspectives. Whilst there is a vast propaganda in favour of the extremist view of Islam, many Muslim scholars have tried to differentiate between the Muslim extremists and the nature of Islam and to argue that Islam in its very nature is peaceful, referring to the Scriptural text and traditions (see Ghani \& Awang 2017; Hobbollah 2011; Tyler 2008:25; for a list of Islamic scholars and politicians condemning terrorism see: Kurzman n.d.). Others have explored the issue from different perspectives, including the status of religious groups in Islamic law (Emon 2012), Jihad (Cook 2005), comparative studies of Islam and the West on the aforementioned issue (Tyler 2008) and the practice of toleration in different Islamic states (Barkey 2005 on the Ottoman Empire). On the other hand, this issue has been a focus of attention in Iran soon after the Islamic Revolution of 1979, whose objective was realisation of Islam as a way of governing. One of the challenges of this new Islamic state at international level was the issue of coexistence with other countries. Considering Iraq's attack on Iran in 1979, some of the political activists expected Imam Khomeini, the founder and leader of the Islamic state in Iran, to declare Jihad, which he never did. This gave rise to the debate on Jihad and the requirements of offensive and defensive Jihad in view of the Shia's stance of prohibiting offensive Jihad in the absence of one of the Infallible Imams. ${ }^{1}$ The traditional prevailing view of Shiite scholars, the same as that of Imam Khomeini, the leader of the Islamic state, was that offensive Jihad was not allowed in the

1.The prevailing Islam in Iran is the twelver Shiism which believes in the legacy of 12 descendants after the Holy Prophet. All of them have passed except for the last one, the Mahdi, who is born and has disappeared but will one day come back with peace and justice. 
absence of the Infallible Imams, that is, at present time, but it was not forbidden generally (see Faghihi 2011). Reconsidering this law, Salehi, an Iranian Shiite jurisprudent for his various critical studies of historical events and traditions, argued that Jihad in Islam was only defensive and offensive Jihad was neither allowed nor practiced at the time of the Prophet (P.B.U.H. [peace be upon him]). According to his research, this theory was adapted by the prominent Shiite scholar and leader, Tusi (d.460 AH/1068 CE), from the famous Sunni jurisprudence, Shafei (d.204 AH/820 CE), and gradually became the prevalent view in Shia (Salehi Najafabadi 2003).

The other challenge encountered by the Islamic government of Iran, which had intimate connections to the issue of tolerance and gained much attention after the Iran-Iraq war, was the issue of coexistence at the national level, considering the presence of minorities from other religions Judaism and Christianity, and other Sunni sects - and also the presence of different religious and political walks within the Iranian society. In this regard, the Islamic rule of 'commanding right and forbidding wrong' needed clarification. There is consensus on this rule amongst different Islamic sects for being mandatory for every Muslim, although they differ on its requirements and limitations (see Cook 2001). It becomes a political challenge when it is practiced according to an individual or a group's interpretation of Islam or the truth and when it goes beyond oral advice to imposing force without any need to refer to a court. This law was the subject of many publications trying to resolve the responsibility of the individual and that of the state, limiting the former to oral advice (see ZargushNasab, Gheybi \& Rezayee 2013) and discussing the appreciated ways of advising others.

Tolerance was also examined considering its theological and philosophical foundations. The Iranian scholar, Soroush, was a pioneer in this debate. He argued for 'pluralism' as a firm foundation for tolerance (Soroush 2009). His argument led to passionate debates with pros and cons. Whilst some supported his arguments partially, others maintained exclusivism or inclusivism (see Azizan 2007; Khusrupanāh 2004:160-207; Rabbani Golpaygani 2009). The philosophical foundation of tolerance from the western view with Islamic foundations has also been comparatively studied focusing on their differences (see Azimi Garekani 2013).

The present article seeks to elucidate Islam's viewpoint about tolerance by examining the four possible ways of confrontation with others, which can be detected in the Qur'an. As the issue is a complex one, isolating the passages in one of these methods will lead to misunderstanding, as the extremists focus on the verses of Jihad without considering the other passages. These four methods of confrontation are as follows:

1. Being indifferent towards opposing beliefs and practices.

2. Taking violent and militant measures (Qital verses).

3. Retreating.

4. Showing tolerance.
The general study of all these four ways of confrontation makes it possible to understand Qur'an's view of this issue, demonstrating the acts with which tolerance can reconcile and those inconsistent with it, therefore clarifying the conditions for showing tolerance more profoundly. Furthermore, in support of Islam's positive view towards tolerance, the theological foundations for tolerance have been discussed. It also has been divided into two different categories: Tolerance in belief and behaviour.

In this study, to explain the position of Islam, the Qur'an, as the main source for the Islamic teachings, has been studied and different exegesis of it, Shiite or Sunni, and also hadiths, have been cited in support of the meaning. By 'Others' any system of belief outside Islam is meant, some of which may be opposing and others just different.

\section{Being indifferent}

Being indifferent towards opposing beliefs and unappreciated behaviours is one of the possible grounds for the formation of tolerance (see Tyler 2008:8). However, this type of confrontation, with regard to the mission of Islam, is with no doubt unacceptable. In the viewpoint of Islam, being indifferent towards wrong beliefs and misbehaviours means confirming them in a sense, and its ill consequences will seize the whole society rather than only the violators. Thus, in the event of killing the camel of God, only the wretched one was responsible, but as all the infidels of the Thamud tribe consented to it, the Holy Qur'an considers all of them guilty of it (see Q91:14 and its interpretation: al-Ṭabarī 1991, xxx:137; Fadlullah 1998, xxiv:287; Hawa 2003, xi:6547; Quṭb 2004, xi:3919). It has also been emphasised in the Hādith that what gathers people together is their like and dislike (Sharif Al-Radii 1993, sermon 201). So, it is mandatory for all walks of life in the society to take action against the improper beliefs and behaviours by heart, tongue and practice (see Sharif Al-Raḍi 1993, sayings 375 and letters 31:392). 'Commanding right and forbidding wrong' as a religious duty addresses all Muslims to clarify their relation towards the true path and not to encourage others to the right and forbid them from the wrong (Hobbollah 2011). There is a consensus on the importance of this issue amongst all different Islamic sects (see Cook 2001). Qur'an (Q9:71) declares:

Believers, whether men or women, must [act as] friends to one another; they should command decency and forbid wickedness, keep up prayer, and pay the welfare tax as well as obey God and His messenger ... (Irving 2009)

Describing the People of the Book, Judaism and Christianity, the Qur'an admires those who observe this rule, taking a stand towards improper behaviours and those who compete with each other in good deeds:

Yet they are not [all] alike: some People of the Book form an upright community; they recite God's verses through the small hours of the night as they bow down on their knees. They believe in God and the Last Day; they command decency and forbid dishonor, and compete in doing good deeds. Those are honorable men. (Q3:113-114) 
Also in 7:159, it declares: 'Out of Moses' folk [there grew] a nation who guided by means of the Truth and dealt justly by means of it' (Irving 2009).

On the other hand, it reprimands those scholars who are indifferent towards improper actions: 'If their rabbis and scholars had only forbidden them from speaking sinfully and living off graft! How wretched is what they have been producing' (Q5:63; Irving 2009)

Imam Ali encourages the Muslims to feel responsible towards the right and the wrong, referring to this same verse as an evidence that the proceeding nations were annihilated because of being indifferent (Kulaynī 1986, v:57). The responsibility of different groups in society is not the same; those more knowledgeable and more powerful are more in charge and have more responsibility than those in lower levels as in the aforementioned verse, where rabbis and scholars representing the well-informed groups of society are criticised for their indifference about the ill practices in their community (Sadeqi Tehrani 1985, ix:75).

It should be mentioned that the 'wrong' and 'right' in beliefs and behaviours to which a Muslim should react are those religious teachings known and accepted widely as such by the public, not special understandings limited to a scholar or a group. In the abovementioned verses, the paired words used for right and wrong are 'ma' ruf and munkar' (translated in English by Irving as decency and dishonour and by Micheal Cook as right and wrong). This word and its derivations occur 40 times in the Qur'an, mostly in relation with different social acts such as interaction with the spouse at the time of marriage and divorce (Q2:228, 232, 233, 234,2 36; 4:19, 25), with parents (Q31:15), concerning those benefiting from a will (Q2:180), in speaking with others $(\mathrm{Q} 4: 5)$ and in encouraging them to good deeds (Q3:104,110; $9: 71,112, \ldots)$. The root of the word 'ma'ruf' is defined as understanding something by thinking and penetrating on its effects (Isfihānī 1991:560-561). Ṭabātabāyī glosses the word as the good practices of the society which are accepted by common sense (Ṭabātabāȳī 2011, viii:380, ii:232), and Zamakhshari defines it as good deeds (Zamakhsharī 1986, ii:190), whilst Alusi sees no reason in limiting it to the word 'No god except Allah' (lä ilāha ill-Allāh) (al-Alusi 1994, v:137).

\section{Taking violent and militant measures}

Speaking of Islam, there is no doubt that Islam does not basically reject war as the holy prophet (P.B.U.H) has participated in various wars with the infidels. But is war in Islam a means for confronting those with opposing beliefs and spreading its cause?

In the Holy Qur'an, the faithful have been ordered to fight for the sake of Allah. The word employed for this subject is 'qital'; contrary to the common understanding, the word jihad is actually neither in its literal meaning nor its Quranic usage equivalent to war. It has been used in this meaning later, but not limited to it. It actually means showing great endeavour in the cause of Allah in all fields of life (see Isfihānī 1991:208):

Let those who barter worldly life for the Hereafter fight for God's sake; We shall pay a splendid fee to anyone who fights in God's way, and is either killed or is victorious. (Q4:74; Irving 2009)

These verses express a general rule praising those ready to give even their lives for the cause of Islam in contrast to the ones preferring this world and its prosperities. It also mentions that a person giving all his belongings, including his life, for the sake of Allah is not an issue only praised in Islam but also in other religions:

God has bought up their persons and their property from believers, so they may have the Garden [instead]. They fight for God's sake; they kill and are killed as a rightful promise from Him [to be found] in the Old Testament, the Gospel and the Qur'an. Who is more Trustworthy with His word than God? So rejoice in your bargain which you have reached with Him. That will be the supreme Achievement. (Q9:111; Irving 2009)

But these verses are silent about the circumstances under which a war should take place.

Regarding the conditions for declaring war, Muslim scholars divide into two groups:

1. One group attests that the only reason for which a war can take place is to defend the Islamic society from any threat concerning their security. It has no eligibility to start a war to spread Islam and to force others to accept this religion. These scholars adduce verses such as 190-194 of Sura alBaqara. In verses 190-194 of Sura al-Baqara, Qur'an has limited fighting and expelling as a counteract to that of the infidels whilst observing the ethical boundaries:

Fight those who fight against you along God's way, yet do not initiate hostilities; God does not love aggressors. (190) Kill them wherever you may catch them, and expel them from anywhere they may have expelled you. Sedition is more serious than killing! Yet do not fight them at the Hallowed Mosque unless they fight you there. If they should fight you, then fight them back; such is the reward for disbelievers. (191) (Irving 2009)

It emphasises observing ethics even in the war: 'And do not exceed the limits Surely Allah does not love those who exceed the limits'.

In line with the circumstances of war, it considers persecution and harassment of the people because of their accepting Islam as much worse than killing someone: 'Sedition (fitna) is more serious than killing! ...' Changing this situation is the objective of these fights: 'Fight them until there is no more subversion and [all] religion belongs to God. If they stop, let there be no [more] hostility except towards wrongdoers' (Q2:193; Irving 2009).

The meaning for 'Al-fitna' (sedition) has been clarified by other verses in the Qur'an:

There are some people who say: 'We believe in God'; yet whenever they suffer abuse for God's sake, they maintain that 
any trials by mankind are like God's torment. If any support should come from your Lord, they would say: 'We have stood alongside you'. Is God not quite aware of what is on the minds of [everybody in] the Universe? (Q29:10; Irving 2009)

But even at the time of war, if the opponents cease fire and accept peace, the arms should be put down and the conflict ended:

Except those who join a folk with whom you have a treaty or who come to you because their breasts shrink from fighting you or fighting with their own people. If God so wished, He would have given them authority over you so that they would have fought you. Yet if they keep aloof from you and do not fight you, and they propose peace to you, God does not grant you any way against them. (Q4:90; Irving 2009)

In addition to the verses of Sura al-Baqara, verses 39-40 of Sura al-Haj can also be mentioned in which those who have been attacked unfairly and made to leave their home are given permission to fight against the aggressors.

2. The second group have a different reading of the earlier mentioned verses of Sura al-Baghara:

a. They define 'fitna' as 'associating others with Allah', that is, 'infidelity', thus interpreting the verse as saying 'Muslims should fight until there is no infidelity'.

b. They take these verses as general, neglecting their context, thus saying:

Kill them wherever you may catch them, and expel them from anywhere they may have expelled you. Sedition is more serious than killing! Yet do not fight them at the Hallowed Mosque unless they fight you there. If they should fight you, then fight them back; such is the reward for disbelievers. (Q2:191; Q10:5; Irving 2009; see al-Alusi, 1994, I :471--472; Hawa, 2003, i: 444 and also Ṭabāṭabāyī 2011, ii:62).

In contrast to their view, the meaning given for 'fitna' is not supported by either its literal meaning or its usage in Qur'an (Darwaza 2000:331-2; Riḍa 2000, ii:210; Salehi Najafabadi 2003:23). The word is actually used for purifying gold with fire (Farāhīdī 1988, I:127) and is used in the Qur'an for the testing of men in their life concerning their belief (Q29:2; Q21:35;Q 64:15) and also for any kind of chastisement in this world, fair or unfair, or in the hereafter (Q8:27;Q85:10; Q29:10; see Isfihānī 1991:623); therefore, 'until they cease' refers to the war, not to their infidelity.

Moreover, in all these verses, the Qur'an is not speaking about the infidels in general but those who have not observed their treaty with the Muslims and have started a fight. In Q2:191 it explicitly orders Muslims to fight with alladhīn yuqatilunakum [those fighting you], as it is the same in Q10:5 in which the same expression is repeated. In the proceeding verses, it talks of two groups of idolaters having treaties with the Muslims. For those who have observed the obligations of their treaty and have not supported the opponents of the Muslims in secret, the treaty with this group is enforced, but the other group violating the peace terms and they are threatened (Q10:1-4).
The study of the battles of the Prophet supports the first view. The Prophet (P.B.U.H) had never started a war. His battles of Badr, Uhud and Khandaq, his attack to Mecca and his war against different tribes were all because of their violation of the peace accord with the Muslims and a response to their military actions. (For a study of the battles of the Prophet Mohammad (P.B.U.H.), see Balāghī 1928, ii:233-241).

The holy Prophet's approach towards the infidels in Mecca clearly shoves away any doubt about the objectives of the war in Islam. In this war, when he entered Mecca, the holy Prophet declared whoever closed the door of his house, not participating in the war, whoever enters the mosque and whoever enters the house of Abu Sofyan, he/ she is secure. The Prophet didn't make them choose between Islam or death, but left them by their infidelity after all their torments and battles against Muslims in the Meccan period and the Medinan era, and the prophet released all of them and stated: 'Go your way, for you are all free' (Ibn Hisham n.d., ii:26).

\section{Retreatment}

Retreating is one form of confrontation with opposing beliefs in which an individual or a group withdraws from a point of view to one intended to lessen conflict. But what is meant here is not any political negotiation between two conflicting groups. It is negotiation on beliefs in such a way that each group puts aside part of their beliefs, reaching a fragmented belief or an integrated one.

In principle, prophets have come to change beliefs rather than to put forth the previous concepts more or less to ease their own job and attract followers. Drawing clear boundaries concerning Islamic and opposing beliefs is an issue which has been emphasised clearly in different verses, including in Sura Al-Kafirun, when the infidels proposed to Muslims worshiping each other's gods periodically (al-Wahidī 1991:496; al-Ṭabarī 1991, xxx:214), and Allah states that each groups' system of thinking is completely separate:

'You have your religion while I have my religion'. (Q109:6; Irving 2009)

The Qur'an prohibits any kind of negotiation in these verses. The main issue of negotiation was who should be worshipped, which is the core of Islam. These verses are silent about the minor issues and whether they can be subject to negotiation or not. Fadhlullah notes that negotiation on minor issues in general is not rejected (Faḍlullah 1998, xxiv:458-9). The same approach is mentioned in other verses:

So do not yield to the rejecters. They wish that you should be pliant so they (too) would be pliant'. (Q68:8 \& 9; Shaker 2003). As it also mentions the fruitfulness of such an act: Even though you brought every sign for those who were given the Book they still would not follow your direction. You are not following their direction, nor will any of them follow one another's direction. If you were to follow their whims once knowledge has come to you, you would then be an evildoer. (Q2:145 and similarly Q2:120; Irving 2009) 


\section{Tolerance}

Despite the fact that Islam rejects withdrawal from what is considered truth, it bears different and opposing beliefs and endures misbehaviour. This is what is meant here by tolerance. Considering the general meaning of tolerance, The Oxford Dictionary gives three definitions for it:

1. The ability or willingness to tolerate the existence of opinions or behaviour that one dislikes or disagrees with.

2. The capacity to endure continued subjection to something such as a drug or environmental conditions without adverse reaction.

3. An allowable amount of variation of a specified quantity, especially in the dimensions of a machine or part. (Tolerance 2018)

Of the three, the first corresponds to the issue considered in this article. In tolerance in its general meaning, the following components are recognisable:

1. Presence of difference and diversity.

2. Presence of dissatisfaction with these beliefs.

3. Not to prohibit others whilst having power and capability.

Considering the meaning of tolerance, this endurance can be viewed in different areas, two of which have been mentioned here: Tolerance in the doctrinal sphere, that is, tolerance in belief, and the one in the scene of practice, that is, tolerance in behaviour.

\section{Tolerance in belief}

A review of the Qur'an shows that Islam believes in tolerance in the scene of belief. Tolerance in Islam does not arise from indifference towards religion and relativity in knowledge, which is one of the important foundations for tolerance in contemporary age. It is grounded in Islam's understanding of the nature of reward and Prophecy.

Nature of reward: The Qur'an introduces humans as free creatures who enjoy sufficient knowledge to distinguish between right and wrong. It is through this very power of selection that humans will enjoy reward and punishment.

The Qur'an describes the resurrection day as the day in which humans will receive whatever they have earned without any injustice:

Today each soul will be rewarded for whatever it has earned. There will be no wrong [done] on that day; God is Swift in reckoning! (Q40:17; Irving 2009)

He could have created all humans uniformly as God believers, but he has not done so, should it be a trial for humans, distinguishing their goodness and evilness so as to reward them accordingly (Ṭabātabāȳ̄ 2011, xii:336; Zamakhsharī 1986, ii:631).

If God had wished, He would have set you up as one community, but He lets anyone He wishes go astray, and guides anyone He wishes. You shall (all) be questioned about whatever you have been doing. (Q16:93, and similar verses:Q5:48; Q42:17 and Q11:118; Irving 2009)

As He reminds that God could bring together all people in one faith: 'If your Lord had so wished, everyone on earth would have believed, all of them together! So will you force mankind to become believers?' (Q10:99; Q6:35 and 107 and Q16:9; Irving 2009)

The nature of prophecy: Based on the previous principle, prophets are only heralds and admonishers who convey the divine message to people. They have not come to force people to prosperity in this world and hereafter. For this very reason, God calls his Prophet as the witness, warner and caller. 'O Prophet, We have sent you as a witness, herald and warner' (Q33:45; Irving 2009).

He reminds His Prophet that he cannot force people to have a faith: 'If your Lord had so wished, everyone on earth would have believed, all of them together! So will you force mankind to become believers?' (Q10:99 and also see: Q17:54; Irving 2009). Țabātabāyī explains that the belief wanted from the people is based on free will, not by force, and this verse points out to the Prophet that he is neither able to force the people to believe in Islam nor should he wish or strive for it (Ṭabātabāyī 2011, x:126; also for the same meaning, see Zamakhsharī 1986, ii:372). On this basis, the Qur'an addresses the Prophet to convey the message to the people accordingly:

SAY: Mankind, Truth has come to you from your Lord! Anyone who accepts guidance is guided only for his own sake; while anyone who strays away, will only become lost at his own risk. I am no custodian set up over you. (Q10:108 and Q39:41; Irving 2009)

The logic of the Qur'an in tolerating opposing belief is based on this freedom in their acceptance and accordingly, it announces:

There should be no compulsion in religion. Normal behavior stands out clearly from error; so anyone who rejects the Arrogant ones and believes in God has grasped the Firmest Handle which will never break. God is Alert, Aware. (Q2:256; Irving 2009)

Islam has appealed to human intellect, asking them to think about its arguments (Q4:82; 47:24). Thus, the way for spreading its cause is only by discussion, wherein the person becomes convinced rationally and their heart submits to its teachings.

Arguing on the basis of wisdom: In line with this ideal, the only way to confront with the other beliefs is through a wise dialogue and good advice:

Invite [people] to your Lord's way with discretion and kindly instruction, and discuss [things] with them in the politest manner. Your Lord is quite aware as to who has strayed from His path, just as He is quite aware of those who have consented to be guided. (Q16:125; Irving 2009) 
As it confirms not to dialogue with the People of the Book except in the best way: 'Do not argue with the People of the Book unless it is in the politest manner, except for those of them who do wrong ...' (Q29:46; Irving 2009). This best way is elaborated in the rest of the verse, by focusing on the common beliefs (Sadeqi Tehrani 1985, xxiii:76):

... SAY: We believe in what has been sent down to us and what has been sent down to you. Our God and your God is [the Same] One, and we are committed to [observe] peace before Him. (Q29:46; Irving 2009)

\section{Tolerance in behaviour}

Besides bearing the opposing beliefs, the behavioural tolerance has a great importance in provision of a society whose capacity to bear Others is high. As tolerance in the scene of belief did not mean being indifferent towards right and wrong, tolerance in the scene of ethics and behaviour does not mean being indifferent towards improper and indecent behaviours as it has been mentioned before. But in practice, the rule dominating the behaviour towards others, either with fellow Muslims or non-Muslims, both concerning their beliefs or behaviours, is to neglect the fallacies and show kindness and gentleness or even more to respond to the evils with kindness: 'Be patient about anything they may say, and steer clear of them in a polite manner' (Q73:10; Irving 2009).

As he and all his followers are ordered to be patient with all the annoying words and acts of their opponents:

You will be tested by means of your wealth and through your own selves, and you will hear much abuse from those who were given the Book before you, as well as those who associate [others with God]. If you are patient and do your duty, that is what will determine matters. (Q3:186; Irving 2009)

and also:

A good deed and an evil deed are not alike: Repel [evil] with something (that is) finer, and notice how someone who is separated from you because of enmity will become a bosom friend! (Q41:34; Irving 2009)

A rule which was fully observed by the holy Prophet as Qur'an reveals it:

However since mercy from God does exist, you have been easy on them. If you had been harsh and cruel-hearted, they would have dispersed from around you. Pardon them, seek forgiveness for them, and consult with them on the matter. Yet once you have reached a decision, then rely on God; God loves those who are reliant. (Q3:159; Irving 2009)

An affection resulting from his heartfelt sympathy for those who had no faith:

Perhaps you will fret yourself to death checking up on them, worrying lest they will not believe this report. (Q18:6; Irving 2009)

Imam Ali's word to his administrator, advising him how to govern his district, best concludes this subject: 'Have mercy with the people, be affectionate and kind, not like greedy beast taking opportunity to eat them.' He then argues that people are of two kinds:

they are of two kinds: either your brethren in religion or your likes in creation. They would commit slips and encounter mistakes. They may act wrongly, willfully or out of negligence. So, extend to them your forgiveness and pardon them in the same way as you would like Allah to extend His forgiveness and to pardon you. (Sharif Al-Raḍi 1993, Letters, 53)

It seems that tolerance in behaviour provides the socialethical grounds for tolerance of belief to spread in the society and become prevalent.

\section{Conclusion}

Tolerance in Islam is a complex act, based on two foundations, that is, the nature of reward and that of prophecy. Whilst it does not lead to indifference, it also rejects any retreatment from the main beliefs of Islam. On the other hand, it reconciles with the rule of commanding right and forbidding wrong which emphasises being responsible towards any true or wrong belief and any good or bad behaviour. It also reconciles with taking militant measures in case of any militant attack and invasion. Considering the field to which it is applied, tolerance in Islam can be divided into tolerance in belief and behaviour. The latter provides the necessary grounds for applying the former.

\section{Acknowledgements Competing interests}

The author declares that he or she has no financial or personal relationships that may have inappropriately influenced him or her in writing this article.

\section{References}

Al-Alūsi, A., 1994, Ar-rooh al-ma'āni fi tafsiri-l-Qur'ani-l-'Azim wa sabb'u-l-mathāni, Dar al-Kutub al-ilmiyah, Beirut.

Al-Ṭabarī, M., 1991, Jāmi' al-bayān fi tafsir al-Qur'an, Dar al-Ma'rifah, Beirut. Al-Wāhidī, A., 1991, Asbab nuzūl al-Quran, Dar al-Kutub al-'Ilmiyyah, Beirut.

Azimi Garekani, H., 2013, 'Barresī Mabānī Falsafĩ Tolerance ba Rūykardī be Tasāmuh va Tasāhul [Studying the philosophical foundations of tolerance with an approach to forbearance and leniency]', Pajouheshaye e ' teqadī Kalamī 3(10), 7-28.

Azizan, M., 2007, 'Plurālīsm Nejāt dar Andīsheh Islamī [Pluralism of salvation in islamic teaching]', Ma'refat 16(121), 13-24.

Balāghī, M.J., 1928, al-Riḥlah al-madrasīyah wa-al-madrasah al-sayyārah fī nahj alhudá, Haidariyeh Library, Najaf.

Barkey, K., 2005, 'Islam and toleration: Studying the Ottoman imperial model, International Journal of Politics, Culture and Society 19,5-19. https://doi. org/10.1007/s10767-007-9013-5

Cook, D., 2005, Undestanding jihad, University of California Press, Berkely, CA.

Cook, M., 2001, Commanding right and forbidding wrong in Islamic thought, Cambridge University Press, Cambridge.

Darwaza, M.I., 2000, al-Tafsir al-hadith, Dar al-Gharb al-Islami, Beirut.

Emon, A.M., 2012, 'Religious minorities and Islamic law: Accomodation and the limits of tolerance', in A.M. Emon, M. Ellis \& B. Glahn (eds.), Islamic law and international human rights law, pp. 323-343, Oxford University Press, Oxford.

Faḍlullah, M.H., 1998, Min wahy al- Qur'an, Dar ol-melak, Beirut.

Faghihi, A., 2011, 'Javaz Jahad Ibtedaȳi ba Izn Faqīh Jāmi؟ Sharāyīt ba Rūykardī bī Ārā'i Imam Khomeini [Allowance of offensive Jihad with permission of completely qualified jurisprendent with an approach to Imam Khomeini's opinion]', Pajuheshnameh Matin 13(50), 135-158.

Farāhīdī, K., 1988, Kitab al-'Ayn, Hejrat, Qom.

Ghani, R.A. \& Awang, J., 2017, A review on writings on religious tolerance in Malaysia, International Journal of Islamic Thought 12(12), 72-82. 
Hawa, S., 2003, Al-Asās fi al-tafsir, Dar al-Salam, Cairo.

Hobbollah, H., 2011, Fegh al-amr bi-I ma'ruf, Dar al-Fiqh al-Islami, Qom.

Ibn Hisham, A.M., n.d., As-Sirah an-Nabawiyyah, Dar al-Ma'rifah, Beirut.

Irving, T.B., 2009, Quran translation (in English), Goodword Books, New Delhi.

Isfihānī, H.R., 1991, al-Mufradāt fĩ gharīb al-Qur'ān, Dar Al-Qalam- Dar Al-Shamieh, Beirut.

Khusrupanāh, A., 2004, Kalām jadīd [new theology], Markaz Mutaleat va pajuheshhay hawzeh elmiyeh Qom, Qom.

Kulaynī, M., 1986, Usūl al-kāfī, Dār al-kutub al-Islamiah, Tehran.

Kurzman, C., n.d., Islamic statements against terrorism, viewed 04 August 2018, from http://kurzman.unc.edu/islamic-statements-against-terrorism/

Tolerance, 2018, Oxford living dictionaries, viewed 03 July 2018, from https:// en.oxforddictionaries.com/definition/tolerance

Quțb, S., 2004. Fì dhilāl al- Qur'an, Dār al-Shuruq, Beirut.

Rabbani Golpaygani, A., 2009, Tahlil va naqd pluralism dinī, Sazman entesharat pajuheshgah farhang va andisheh Islami, Tehran.
Riḍa, M.R., 2000, al-Manar, Dār al-Ma'rifah, Beirut.

Sadeqi Tehrani, M., 1985, Al-Forghan fi tafsir al-Qur'an, Farhang Islami, Qom.

Salehi Najafabadi, N., 2003, Jihad fi al-Islam, Ney, Tehran.

Shaker, M.H., 2003, Holy Qur'an, Ansariyan Publications, Qom.

Sharif Al-Raḍi, M., 1993, Nahj al-Balagha, Hejrat, Qom.

Soroush, A., 2009, Serat-hayeh mostaqim, Serat, Tehran.

Țabāțabāȳ̄, M.H., 2011, al-Mīzān fī tafsīr al-Qur'an, Mu'assisah al-A'lamī LilMațbū'āt, Beirut.

Tyler, A., 2008, Islam, the West, and tolerance: Conceiving coexistance, Palgrave Macmillan, New York.

Zamakhsharī, M., 1986, al-Kashshāf 'an Haqū'iq ghawāmid al-tanzīl, Dār al-Kitāb al'Arabī, Beirut.

Zargush-Nasab, A., Gheybi, S.M. \& Rezayee, S., 2013, 'Amr be Ma'ruf va Nahy az Munkar az Manzar Fiqh va Huqūq va Barresī Jāygah Dulat va Mellat [Commanding right and forbidding wrong in view of jurisprudence and law and studying the status of state and citizens]', Andishehayeh huquq umumi 2(4), 27-48. 